Article

\title{
Cloning and Functional Characterization of Two 4-Coumarate: CoA Ligase Genes from Selaginella moellendorffii
}

\author{
Xin-Yan Liu, Ping-Ping Wang, Yi-Feng Wu, Ai-Xia Cheng * and Hong-Xiang Lou * \\ Key Laboratory of Chemical Biology of Natural Products, Ministry of Education, School of Pharmaceutical \\ Sciences, Shandong University, Jinan 250012, China; qqbailiu@163.com (X.-Y.L.); \\ wangpingp1234@163.com (P.-P.W.); wendywu.12@163.com (Y.-F.W.) \\ * Correspondence: aixiacheng@sdu.edu.cn (A.-X.C.); louhongxiang@sdu.edu.cn (H.-X.L.); \\ Tel.: +86-531-8838-2012 (A.-X.C.); Fax: +86-531-8838-2019 (A.-X.C.)
}

Received: 6 February 2018; Accepted: 26 February 2018; Published: 7 March 2018

\begin{abstract}
Selaginella is an extant lycopodiophyte genus, which is representative of an ancient lineage of tracheophytes. The important evolutionary status makes it a valuable resource for the study of metabolic evolution in vascular plants. 4-coumarate: CoA ligase (4CL) is the pivotal enzyme that controls the flow of carbon through the phenylpropanoid metabolic pathway into the specific lignin, flavonoid, and wall-bound phenolics biosynthesis pathways. Although 4CLs have been extensively characterized in other vascular plants, little is known of their functions in Selaginella. Here, we isolated two 4CL genes (Sm4CL1 and Sm4CL2) from Selaginella moellendorffii. Based on the enzymatic activities of the recombinant proteins, both of these genes encoded bona fide 4CLs. The 4CL isoforms in S. moellendorffii have different activities: Sm4CL2 was more active than Sm4CL1. The enzymatic properties and gene expression patterns indicated that the $4 C L$ genes have been conserved in the evolution of vascular plants.
\end{abstract}

Keywords: Selaginella moellendorffii; 4-coumarate: CoA ligase; biochemical characterization

\section{Introduction}

Phenylpropanoids are plant-specific natural products that serve important functions during growth, development, and environmental interactions [1]. Phenylpropanoids are synthesized from phenylalanine via the central phenylpropanoid pathway, which is mediated by phenylalanine ammonia-lyase (PAL), cinnamate 4-hydroxylase $(\mathrm{C} 4 \mathrm{H})$, and 4-coumarate: CoA ligase (4CL). 4-coumarate: CoA ligase (EC 6.2.1.12) catalyzes the conversion of several hydroxycinnamic acids into their corresponding CoA esters, enabling the biosynthesis of a diverse array of natural products (Figure 1), including lignin, flavonoids, and wall-bound phenolics [2-4]. The multiple functions of $4 C L$ might explain why it is encoded by a gene family present in plants. The $4 C L$ gene family has four members in Arabidopsis thaliana [5], five members in Oryza sativa [6], and four members in Physcomitrella patens [7]. The catalytic properties of 4CL protein isoforms have been studied extensively. In some species, such as potato and parsley, cloned genes encode identical, or nearly identical, proteins that possess similar substrate affinities [8,9]. In other plants, such as aspen trees and Arabidopsis, structurally- and functionally-divergent protein isozymes have been isolated [5,10].

Selaginella, also known as spikemoss, is the only surviving genus within the Selaginellaceae. This genus first appears in the fossil record some 400 million years ago. Selaginellaceae, together with two other extant families (Lycopodiaceae, the clubmosses, and Isoetaceae, the quillworts), comprise the division Lycopodiophyta, the oldest extant lineage of vascular plants [11]. Over the last several decades, the isolation and structural elucidation of phenylpropanoids from the Selaginella genus has 
expanded. In vascular plants, deposition of lignin is of significance because it reinforces plant cell walls, facilitates water transport, provides compressive strength to conducting tissues, and acts as a mechanical barrier to pathogens. Additionally, previous investigations revealed the genus Selaginella to be a rich source of flavonoids, including monomeric flavonoids and biflavonoids [12]. However, little is known about the genes in the phenylpropanoid pathways of Selaginella species. Recently, the genome of $S$. moellendorffii was sequenced by the Joint Genome Institute (JGI) because of its important evolutionary position among land plants and its small genome size; S. moellendorffii is, therefore, an important new model species $[13,14]$. Here, we isolated and identified two 4CL genes (Sm4CL1 and Sm4CL2) from S. moellendorffii. The activities of these two enzymes were substantially different. We also measured the organizational expression patterns of the two genes.

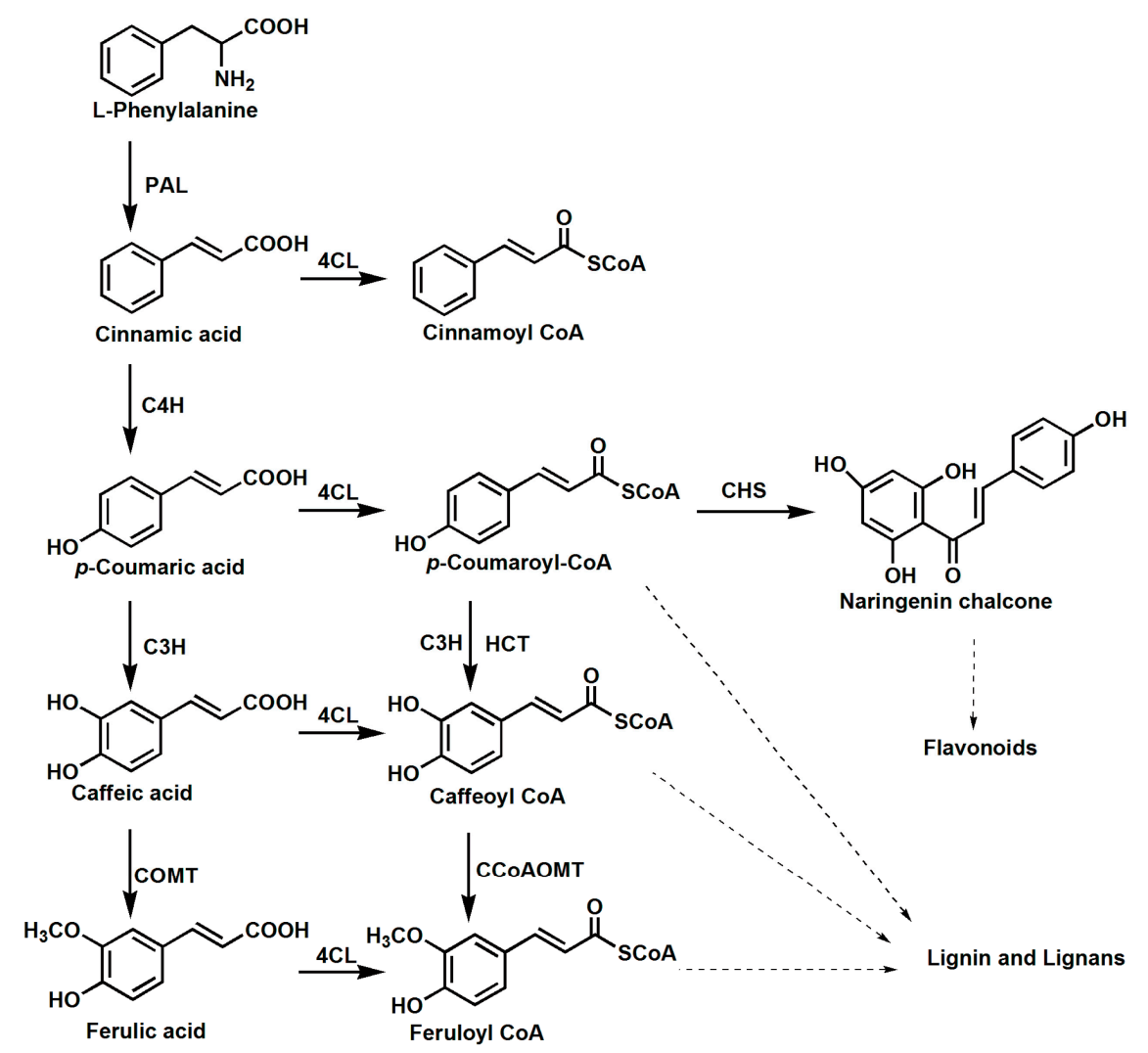

Figure 1. The proposed synthesis pathway of phenylpropanoids in Selaginella moellendorffii. PAL: phenylalanine ammonia lyase, $\mathrm{C} 4 \mathrm{H}$ : cinnamate 4-hydroxylase, 4CL: 4-coumarate: CoA ligase, C3H: 4-coumarate 3-hydroxylase, COMT: caffeic acid O-methyl transferase, HCT: $p$-hydroxy cinnamoyl transferase, CCoAOMT: caffeoyl-CoA O-methyltransferase, CHS: chalcone synthase.

\section{Results}

\subsection{Identification of 4CL Genes from S. moellendorffii}

We identified and cloned two putative 4CL genes (Sm4CL1: GenBank accession number XP_002969881; Sm4CL2: XP_002979073) from the S. moellendorffii genome. The ORF of Sm4CL1 was $1614 \mathrm{bp}$, predicting a protein of 537 residues, with a molecular mass of $57.34 \mathrm{kDa}$ and a pI of 5.88. The ORF of Sm4CL2 was $1695 \mathrm{bp}$, predicting a protein of 564 residues, with a molecular mass of $61.56 \mathrm{kDa}$ and a $\mathrm{pI}$ of 5.87. Sm4CL1 contained five exons and four introns, while Sm4CL2 contained six exons and five introns (Figure 2). Sm4CL genes had multiple introns and exons, consistent with $4 C L$ genes in other species [7]. 

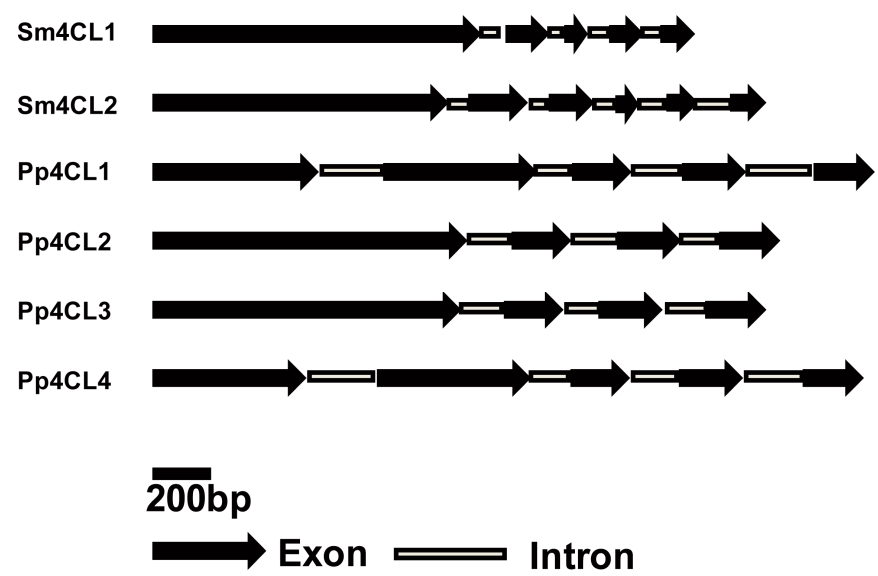

Figure 2. Genome structure of $S m 4 C L s$ and other plant $4 C L$ genes. Schematic diagrams with exons (black arrow) and introns (gray box). The gene accession numbers are as follows: Pp4CL1 (Physcomitrella patens): EU167552; Pp4CL2 (P. patens): EU167553; Pp4CL3 (P. patens): EU167554; Pp4CL4 (P. patens): EU167555.

\subsection{Protein Sequence and Phylogenetic Analysis of Sm4CLs}

The predicted proteins Sm4CL1 and Sm4CL2 had 55-60\% sequence identity with 4CL proteins in other species of plants (At4CL2 and Pt4CL). Our multiple sequence alignment indicated that both Sm4CLs contained two motifs that are conserved across the 4CL family in plants: a putative AMP-binding motif (box I) and a conserved box II "GEICIRG" domain (Figure 3). The central cysteine residue of box II might be involved in catalysis [15].

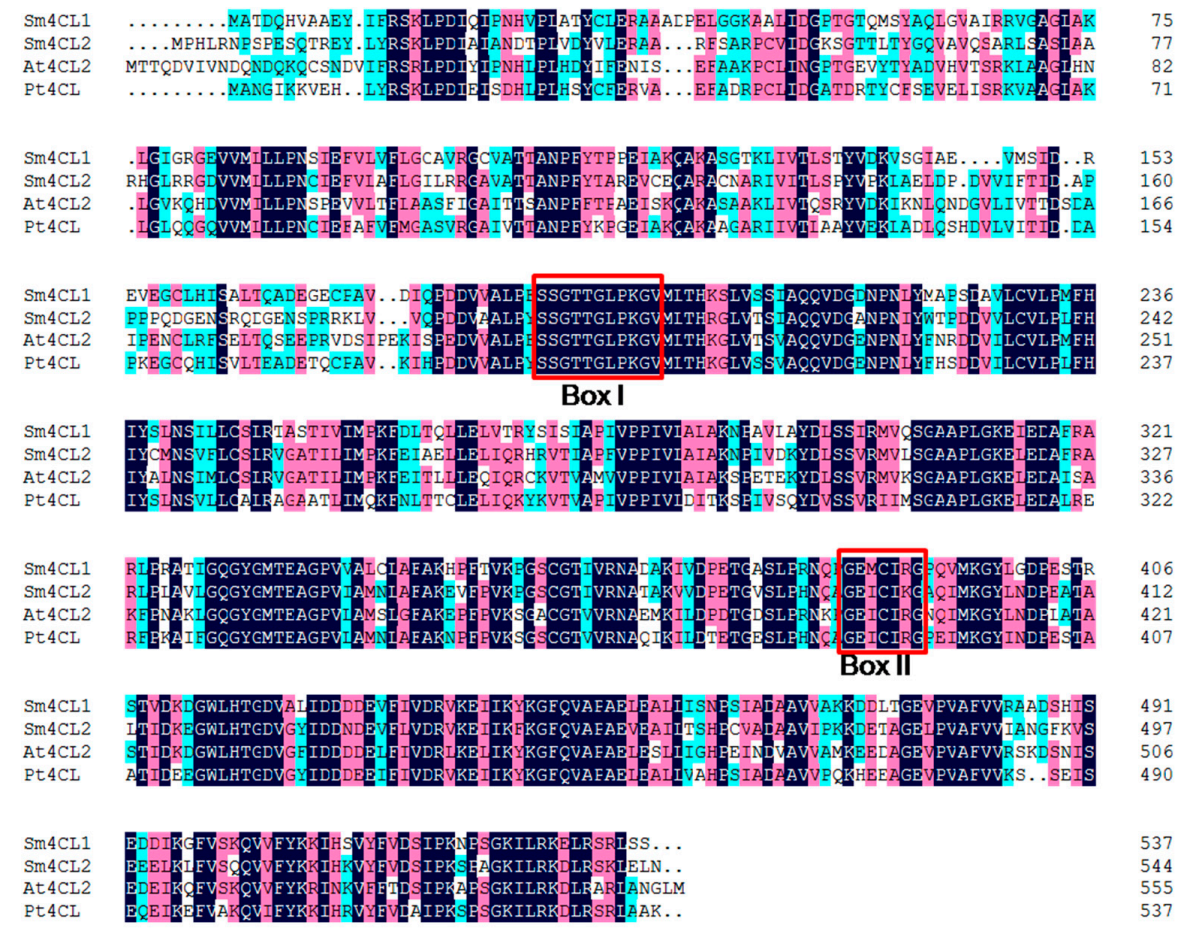

Figure 3. Sequence alignment of Sm4CLs with other plant 4CLs. Box I represents the putative AMP-binding domain, and box II represents the conserved "GEICIGR" putative catalytic site. Sequence accession numbers are given in Supplementary Data Table S2. 
Our neighbor-joining phylogenetic analysis divided the 4CL proteins into four clades: one clade of Sm4CL1, Sm4CL2, and 4CL proteins from mosses and gymnosperms; and three angiosperm 4CL clades (class I, class II, and class III) (Figure 4). Angiosperm class I 4CLs are more closely associated with lignin biosynthesis, as demonstrated by antisense and RNAi suppression studies [6,16,17]. Angiosperm class II 4CLs are likely involved the biosynthesis of other phenolic compounds, based on their compartmentalized expression in various plant organs and tissues $[10,18]$. Angiosperm class I and II 4CLs are predominantly present in dicots, whereas class III 4CLs are largely restricted to monocots.

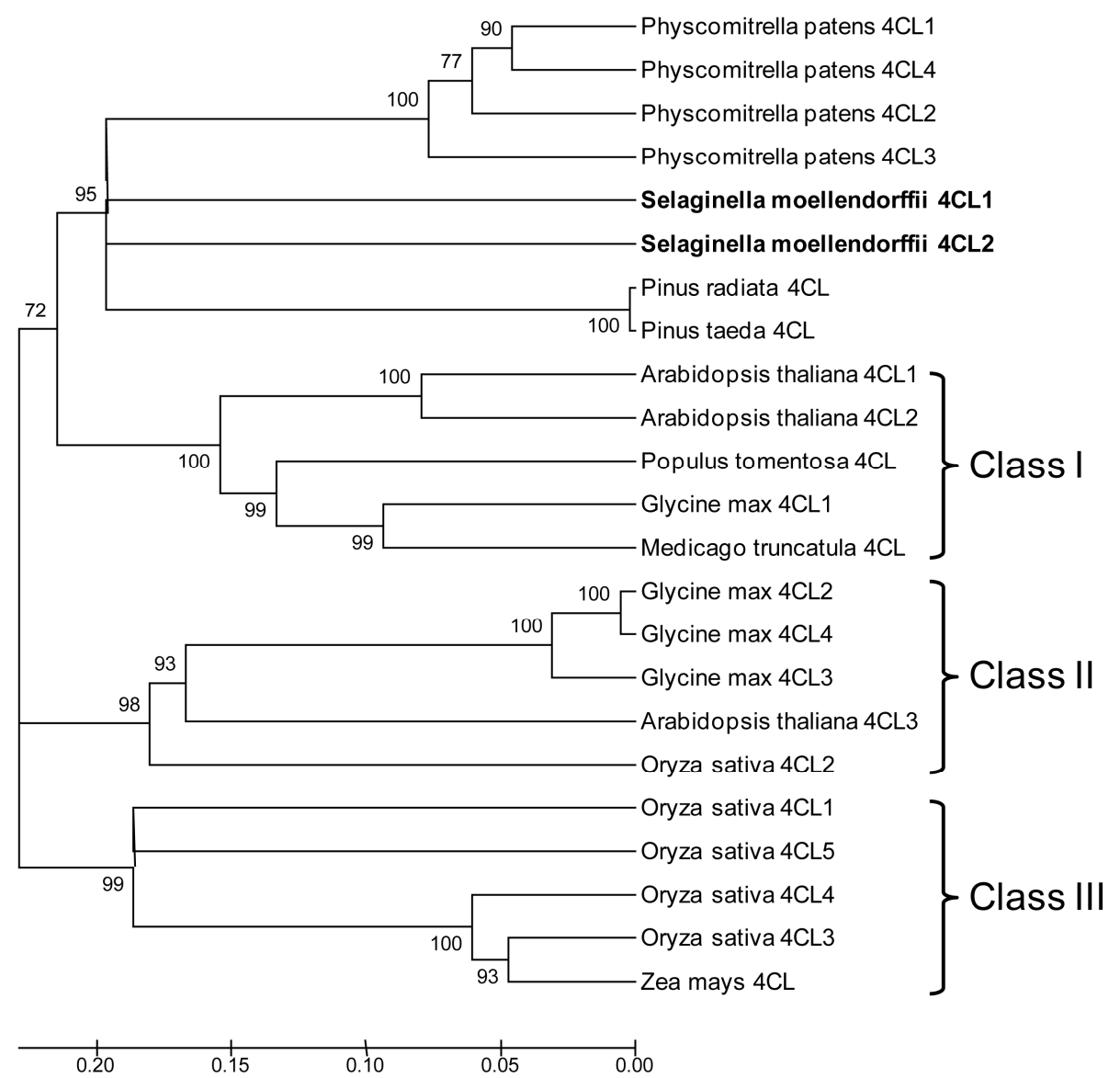

Figure 4. Neighbor-joining phylogeny of Sm4CLs and previously published 4CL gene sequences from other species. Sequence accession numbers are given in Supplementary Data Table S2.

\subsection{Biochemical Characterization of Recombinant Sm4CL In Vitro}

We examined the biochemical properties of the Sm4CLs by synthesizing these enzymes in Escherichia coli. Following purification of the corresponding recombinant 4CLs, fractionation with sodium dodecyl sulfate polyacrylamide gel electrophoresis (SDS-PAGE) showed that the molecular masses were between 75 and $79 \mathrm{kDa}$ (including the tags) (Figure 5). We tested whether the purified proteins utilized $p$-coumaric acid, dihydro- $p$-coumaric acid, trans-cinnamic acid, caffeic acid, ferulic acid, and sinapic acid. Both Sm4CL1 and Sm4CL2 had distinct CoA ligation activity with all substrates except sinapic acid (Table 1). Reaction products were identified by HPLC using $p$-coumaroyl CoA, dihydro- $p$-coumaroyl CoA, caffeoyl CoA, and feruloyl CoA as product standards (Figure 6). We determined the effects of $\mathrm{pH}$ and temperature on the enzyme activity with $p$-coumaric acid as substrate. The enzymatic activities of the Sm4CLs were $\mathrm{pH}$-dependent and temperature-sensitive. The optimum $\mathrm{pH}$ for both Sm4CL1 and Sm4CL2 was about 7.0. The optimum temperature for Sm4CL1 was $40{ }^{\circ} \mathrm{C}$, while for Sm4CL2, it was $50{ }^{\circ} \mathrm{C}$. Under optimal conditions, recombinant Sm4CL1 showed a high affinity for $p$-coumaric acid $(\mathrm{Km}=11.89 \mu \mathrm{M})$ and caffeic acid $(\mathrm{Km}=10.87 \mu \mathrm{M})($ Table 2$)$. However, 
the substrate turnover rate (kcat) was higher with $p$-coumaric acid than with caffeic acid, resulting in a higher catalytic efficiency (kenz) with $p$-coumaric acid. Thus, $p$-coumaric acid was the best substrate for Sm4CL1.

Similarly, Sm4CL2 showed a higher affinity for $p$-coumaric acid $(\mathrm{Km}=19.67 \mu \mathrm{M})$ and caffeic acid $(\mathrm{Km}=18.96 \mu \mathrm{M})$, and a higher substrate turnover rate with $p$-coumaric acid, ferulic acid, and dihydro- $p$-coumaric acid (Table 2). Based on the $\mathrm{Km}$ value and the substrate turnover rate, we considered $p$-coumaric acid the best substrate for Sm4CL2.

We also found that the turnover rate of Sm4CL2 was much higher than that of Sm4CL1: the kcat of $p$-coumaric acid for Sm4CL2 was $42.91 \mathrm{~min}^{-1}$, and while that of Sm4CL1 was only $4.09 \mathrm{~min}^{-1}$.

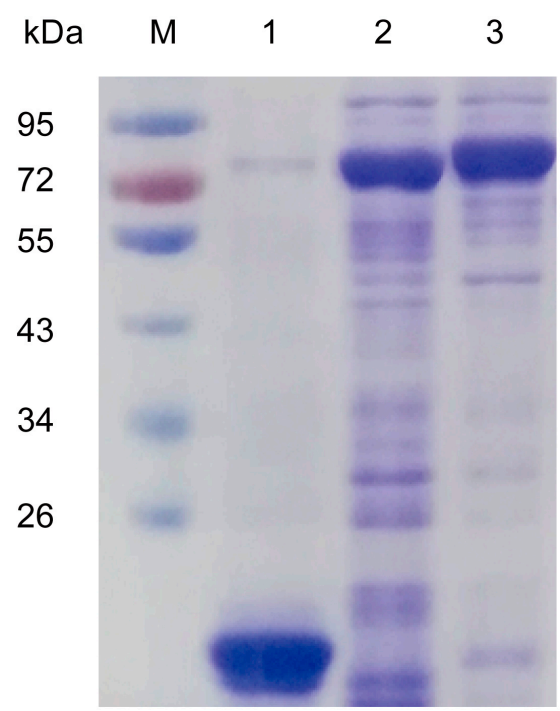

Figure 5. SDS-PAGE analysis of purified recombinant proteins from E. coli. Lane M: molecular mass standards; lane 1: empty pET32a vector; lane 2: pET32a-Sm4CL1; lane 3: pET32a-Sm4CL2.

Table 1. The substrate specificity of Sm4CLs.

\begin{tabular}{lll}
\hline \multirow{2}{*}{ Substrate } & \multicolumn{2}{l}{ Specific Activity $\left(\mathbf{n m o l ~} \mathbf{~ g}^{-\mathbf{1}} \mathbf{~ m i n}^{\mathbf{- 1}}\right)$} \\
\cline { 2 - 3 } & Sm4CL1 & Sm4CL2 \\
\hline$p$-coumaric acid & $71.77 \pm 0.31$ & $557.5 \pm 15.58$ \\
caffeic acid & $16.92 \pm 0.2$ & $239.71 \pm 5.6$ \\
cinnamic acid & $2.29 \pm 0.08$ & $283.08 \pm 5.22$ \\
ferulic acid & $1.14 \pm 0.00$ & $494.83 \pm 3.61$ \\
dihydro- $p$-coumaric acid & $16.71 \pm 0.45$ & $271.77 \pm 29.57$ \\
sinapic acid & ND & ND \\
\hline
\end{tabular}

ND: No detectable activity.

Table 2. Kinetic parameters of Sm4CLs.

\begin{tabular}{|c|c|c|c|c|c|}
\hline Enzyme & Substrate & $\mathrm{Km}(\mu \mathrm{M})$ & $\begin{array}{l}\text { Vmax } \\
\left(\mathrm{nmol} \mathrm{mg}^{-1} \min ^{-1}\right)\end{array}$ & kcat $\left(\min ^{-1}\right)$ & $\operatorname{kenz}\left(M^{-1} \min ^{-1}\right)$ \\
\hline \multirow{3}{*}{ Sm4CL1 } & $p$-coumaric acid & $11.89 \pm 1.56$ & $71.37 \pm 2.58$ & $4.09 \pm 0.15$ & $343,986.54$ \\
\hline & caffeic acid & $10.87 \pm 1.6$ & $25.40 \pm 0.94$ & $1.46 \pm 0.05$ & $134,314.63$ \\
\hline & di- $p$-coumaric acid & $442.4 \pm 53.74$ & $43.73 \pm 1.34$ & $2.51 \pm 0.08$ & 5673.6 \\
\hline \multirow{5}{*}{ Sm4CL2 } & $p$-coumaric acid & $19.67 \pm 2.92$ & $697.1 \pm 32.06$ & $42.91 \pm 1.97$ & $2,181,494.66$ \\
\hline & caffeic acid & $18.96 \pm 2.61$ & $268.1 \pm 9.74$ & $16.50 \pm 0.60$ & $870,253.16$ \\
\hline & cinnamic acid & $126.9 \pm 11.57$ & $382 \pm 9.31$ & $23.52 \pm 0.57$ & $185,310.64$ \\
\hline & ferulic acid & $95.99 \pm 13.39$ & $525.2 \pm 21.18$ & $32.33 \pm 1.3$ & $336,819.59$ \\
\hline & di- $p$-coumaric acid & $220.1 \pm 36.86$ & $673.1 \pm 23.19$ & $41.44 \pm 1.43$ & $188,278.06$ \\
\hline
\end{tabular}



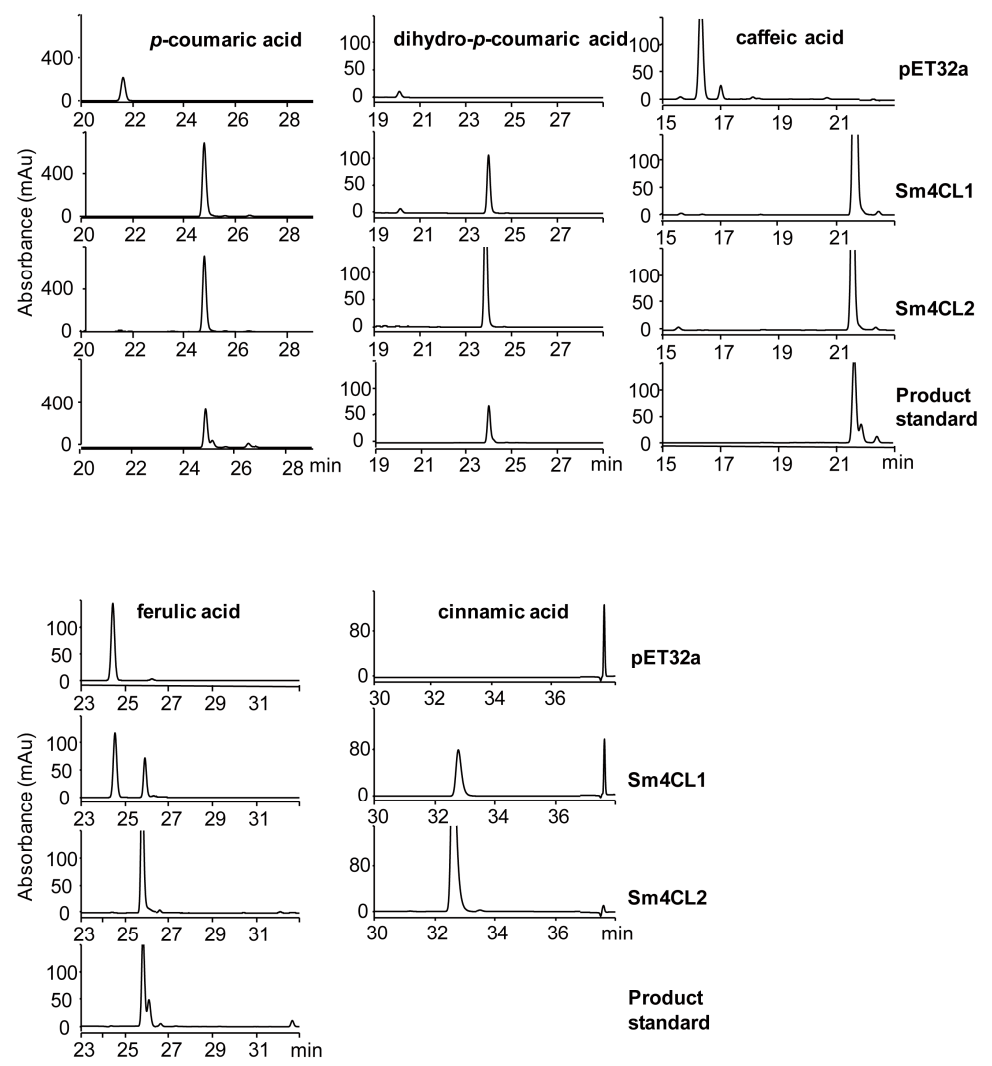

Figure 6. HPLC profiles of reaction products generated by recombinant Sm4CLs. Recombinant Sm4CL enzymes were provided with $p$-coumaric acid, dihydro- $p$-coumaric acid, caffeic acid, ferulic acid, and cinnamic acid as substrates. We used a bacterial clone inoculated with an empty pET32a vector to produce the control reaction product.

\subsection{Determination of Gene Expression Patterns in Tissues}

Transcription of Sm4CL1, Sm4CL2 was detected in roots, stems and leaves, but the expression level of the two genes was different. Sm4CL1 was most highly expressed in roots, then stems, then leaves. Sm4CL2 was also the most highly expressed in roots like Sm4CL1, but its expression level in the leaves was higher than in the stems (Figure 7).

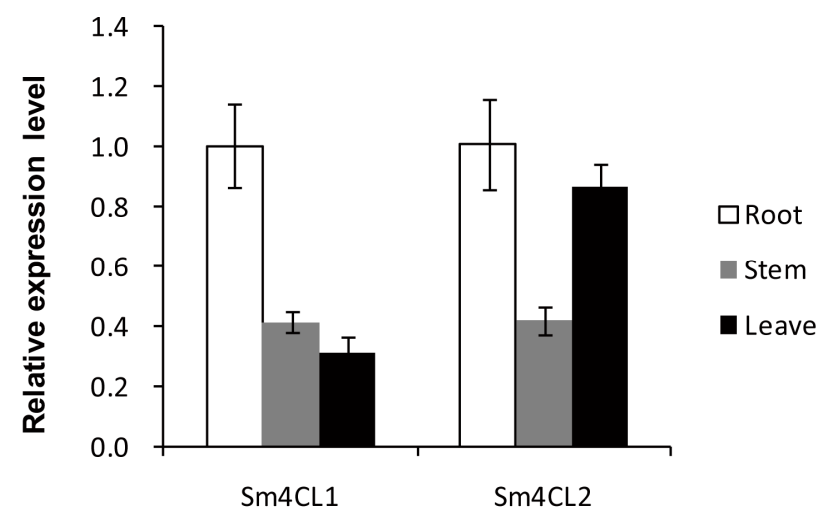

Figure 7. Expression of $S m 4 C L$ genes in roots, stems, and leaves of $S$. moellendorffii. Values represent the mean $\pm \mathrm{SD}$, measured from at least three biological replicates. 


\section{Discussion}

Selaginella species are evolutionarily important among land plants: these are the oldest vascular plants and are distinguished from primitive bryophytes by the development of vascular tissue capable of transporting fluids throughout the plant body. $4 \mathrm{CL}$ is the pivotal enzyme that controls the flow of carbon through the phenylpropanoid metabolic pathway into the specific lignin, flavonoid, and coumarin biosynthesis pathways. The $4 C L$ genes have been widely investigated in other lineages of vascular plants, but little is known about $4 C L$ genes in Selaginella. A better understanding of the $4 C L$ genes in Selaginella will inform our understanding of the evolution of 4CLs across all vascular plants.

We cloned two $4 C L$ genes from S. moellendorffii, based on the enzymatic activities of the recombinant proteins, both of these genes encoded bona fide 4CLs. This was consistent with previous reports that the $4 C L$ genes exist as a gene family in most vascular plants $[10,19-21]$. We noticed that the properties of the $S m 4 C L$ genes we investigated were similar to those of $4 C L s$ in other vascular plants: their genetic structure was made up of multiple introns and exons, they contained conserved putative catalytic domains, and they had close phylogenetic relationships with other vascular plant 4CLs. Sm4CL1 and Sm4CL2 were more highly expressed in the roots than in the stems or the leaves; this is consistent with previous studies [22-24]. These results indicated the 4CL genes are evolutionarily conserved, underlining the importance of $4 \mathrm{CL}$ as a key enzyme in the phenylpropanoid metabolism of all vascular plants.

Although the Sm4CL1 and Sm4CL2 isoforms clustered together in our phylogeny, the activities of these two enzymes were substantially different. The catalytic efficiency of Sm4CL2 toward hydroxycinnamic acids was similar to that of other plant 4CLs $[22,23,25,26]$, but the enzymatic activity of Sm4CL1 toward hydroxycinnamic acids was weak. Our kinetic analysis indicated that Sm4CL2 efficiently catalyzed the conversions of $p$-coumaric acid, caffeic acid, and ferulic acid into their corresponding CoA esters. Meanwhile, lignin in Selaginella species is comprised of three major types of aromatic units: $p$-hydroxyphenyl $(\mathrm{H})$, guaiacyl $(\mathrm{G})$, and syringyl $(\mathrm{S})$, which are derived from $p$-coumaryl alcohol, coniferyl alcohol, and sinapyl alcohol, respectively [3,27-31]. Therefore, it is likely that Sm4CL2 plays a role in the biosynthesis of the $p$-hydroxyphenyl and guaiacyl lignin subunits. The lack of any detectable conversion of sinapate by each Sm4CL isoforms, and the existence of ferulate 5-hydroxylation and $O$-methylation pathway which operates on feruloyl-CoA to produce sinapoyl-CoA [32,33], suggested that the biosynthesis of sinapyl alcohol and syringyl lignin occurs via an independent $4 \mathrm{CL}$ pathway in S. moellendorffii.

In summary, we identified two $4 C L$ genes from the S. moellendorffii genome. These genes were expressed in all tested organs. Our bioinformatic characterization and in vitro enzyme assay indicated that typical $4 C L$ genes were evolutionarily conserved across the vascular plants. The enzyme activities of Sm4CLs were interesting, which included a highly-active enzyme and a very weakly active enzyme. This paper provides a framework for future work on the phenylpropanoid metabolic pathway in $S$. moellendorffii.

\section{Materials and Methods}

\subsection{Plant Material, Nucleic Acid Extraction, and Reagents}

S. moellendorffii was grown in a greenhouse under controlled conditions: $25{ }^{\circ} \mathrm{C}$ with a $12 \mathrm{~h}$ photoperiod. Genomic DNA was extracted from fresh ferny foliage using the CTAB method [34]. Total RNA was extracted from foliage using the modified CTAB method [35], and was used as a template for cDNA synthesis using PrimeScript RT Master Mix (Takara, Otsu, Japan), following the manufacturer's protocols. All chemicals and reagents were purchased from Sigma-Aldrich (St. Louis, MO, USA), unless otherwise indicated. $p$-Coumaroyl CoA, dihydro- $p$-coumaroyl CoA, caffeoyl CoA, and feruloyl CoA were enzymatically synthesized following previously-published procedures [36-38]. 


\subsection{DNA Isolation and Sequence Analysis}

We identified two putative 4CL genes in the genome of S. moellendorffii v.1.0 (http:/ / phytozome. jgi.doe.gov / pz/portal.html) [39] using the TblastN algorithm and designated these putative genes Sm4CL1 and Sm4CL2. The full-length cDNA sequences of these genes were amplified using the corresponding primer pairs (Sm4CL1-F/R, Sm4CL2-F/R; Supplementary Data Table S1). The Sm4CL genomic DNA sequences were also obtained from genomic DNA with the same corresponding primer pairs (Supplementary Data Table S1). Predicted polypeptide sequences were aligned using DNAMAN v.7.0.2 (Lynnon Corp., Vaudreuil-Dorion, QC, Canada). Neighbor-joining phylogenetic trees were constructed using MEGA v5.0 [40]. We tested tree robustness by running 1000 bootstrap replicates.

\subsection{Recombinant Protein Expression and Purification}

The open reading frames (ORFs) of Sm4CL were amplified with pET primer pairs (Table S1), and subcloned into a pET32a vector. After the sequences were confirmed, each construct was transformed into Escherichia coli strain BL21 (DE3) for heterologous expression. The transgenic cultures were incubated at $37{ }^{\circ} \mathrm{C}$ until the $\mathrm{OD}_{600}$ reached $0.4-0.6$, then the recombinant proteins were induced at $16{ }^{\circ} \mathrm{C}$ for $16 \mathrm{~h}$ after adding $0.5 \mathrm{mM}$ isopropyl $\beta$-D-1-thiogalactopyranoside (IPTG). N-terminal hexahistidine-tagged proteins were purified by passing through a Ni-NTA Sefinose His-bind column (Bio Basic Inc., Markham, ON, Canada), and then were exchanged through an Ultrafiltration tube (Millipore, Billerica, MA, USA) in the presence of binding buffer (20 mM Tris- $\mathrm{HCl}, 500 \mathrm{mM} \mathrm{NaCl}$, $\mathrm{pH}$ 8.0). Protein concentrations were determined with the Bradford reagent (Beyotime, Shanghai, China), using BSA as a standard. The resulting purified proteins were monitored on SDS-PAGE, using Coomassie Blue R250 staining. The migration of standard molecular weight markers (10-170 kDa) (Fermentas, Waltham, MA, USA) was used to estimate the molecular masses of the target proteins.

\subsection{Enzyme Assays}

We performed Sm4CLs enzyme assays to detect the formation of the CoA esters of various cinnamic acid derivatives. Each $200 \mu \mathrm{L}$ assay contained $10 \mu \mathrm{g}$ purified protein, $200 \mu \mathrm{M}$ substrate, $5 \mathrm{mM}$ $\mathrm{ATP}, 300 \mu \mathrm{M} \mathrm{CoA}$, and $5 \mathrm{mM} \mathrm{MgCl}_{2}$, made up in $200 \mathrm{mM}$ Tris-HCl buffer (pH 7.5). Enzymatic reactions were incubated for $30 \mathrm{~min}$ at $30{ }^{\circ} \mathrm{C}$, and the reaction products were analyzed using a HPLC device (1260 Infinity Binary LC system, Agilent, Santa Clara, CA, USA), equipped with a multi wavelength detector. The samples were separated through a 5- $\mu \mathrm{m}$ reverse-phase XDB-C18 column with a flow rate of $1 \mathrm{~mL} / \mathrm{min}$. A linear gradient of solvent $\mathrm{A}\left(1 \% \mathrm{H}_{3} \mathrm{PO}_{4}\right.$ in $\left.\mathrm{H}_{2} \mathrm{O}\right)$ and solvent $\mathrm{B}\left(\mathrm{CH}_{3} \mathrm{CN}\right)$ were applied as follows: 0-5 $\mathrm{min}, 5 \% \mathrm{~B}$ isocratic; 5-35 min, 5-25\% B linear; 35-36 min, 25-100\% B linear. Standard solutions of reference compounds were used for calibration.

The effects of $\mathrm{pH}$ and temperature on the enzyme activity were examined using $p$-coumaric acid as substrate. To determine optimal $\mathrm{pH}$, enzymatic activity was assessed in $200 \mathrm{mM}$ Tris- $\mathrm{HCl}$ buffer (pH 5.0, 6.0, 6.5, 7.0, 7.5, 8.0, 8.5, and 9.0), while the optimal temperature was determined by measuring enzymatic activity at $10,20,30,40,50$, and $60^{\circ} \mathrm{C}$. All experiments were performed in triplicate. Kinetic parameters were determined using different substrate concentrations. We performed this experiment in triplicate, with $3 \mu \mathrm{g}$ purified enzyme in a final volume of $200 \mu \mathrm{L}$ of $200 \mathrm{mM} \mathrm{Tris- \textrm {HCl }}$ buffer at the optimal $\mathrm{pH}$ and temperature for $10 \mathrm{~min}$. The level of UV absorption was recorded at 1 min intervals. Relevant wavelengths were $311 \mathrm{~nm}$ (cinnamoyl CoA), $333 \mathrm{~nm}$ ( $p$-coumaroyl CoA), $346 \mathrm{~nm}$ (caffeoyl CoA), 346 nm (feruloyl CoA), and $352 \mathrm{~nm}$ (sinapoyl CoA) [37,41,42]. For determining kinetic properties with dihydro- $p$-coumaric acid, reactions were incubated at optimal temperature for $10 \mathrm{~min}$ and analyzed using HPLC, and then the quantity of the reaction product present was estimated from a standard calibration curve. 


\subsection{Expression Profile Analysis}

For real-time quantitative PCR, various S. moellendorffii tissues (roots, stems, and leaves) were collected and snap-frozen in liquid $\mathrm{N}_{2}$. Total RNA was extracted and cDNA was synthesized as described above. Transcript abundance was quantified using real-time quantitative PCR based on the corresponding RT primer pairs (sequences given in Table S1), using an Eppendorf Mastercycler ep realplex RealTime PCR System (Eppendorf, Hamburg, Germany). Each $10 \mu \mathrm{L}$ reaction contained $1 \mu \mathrm{g}$ cDNA, $0.5 \mu \mathrm{M}$ of each primer, and $1 \times$ SYBR Green PCR Master mix. A fragment of the S. moellendorffii geneome encoding an actin gene was used as the internal reference sequence and was amplified using primers Smactin-RTF/R (Table S1).

Supplementary Materials: The following are available online. Table S1: Primer sequences used in this research, Table S2: Accession numbers of amino acid sequences used for phylogenetic reconstruction.

Acknowledgments: We are grateful for the support of the National Natural Science Foundation of China (no. 81630093 and no. 31370330).

Author Contributions: Ai-Xia Cheng and Hong-Xiang Lou designed the research. Xin-Yan Liu performed most of the experiments with the help of Ping-Ping Wang and Yi-Feng Wu. Ai-Xia Cheng and Xin-Yan Liu wrote the paper. All authors discussed the results and edited the article and approved the final manuscript.

Conflicts of Interest: The authors declare that there is no conflict of interest in the present investigation.

\section{References}

1. Vogt, T. Phenylpropanoid biosynthesis. Mol. Plant 2010, 3, 2-20. [CrossRef] [PubMed]

2. Dixon, R.A.; Achnine, L.; Kota, P.; Liu, C.J.; Reddy, M.S.; Wang, L. The phenylpropanoid pathway and plant defence-a genomics perspective. Mol. Plant Pathol. 2002, 3, 371-390. [CrossRef] [PubMed]

3. Boerjan, W.; Ralph, J.; Baucher, M. Lignin biosynthesis. Annu. Rev. Plant Biol. 2003, 54, 519-546. [CrossRef] [PubMed]

4. Vassão, D.G.; Kim, K.-W.; Davin, L.B.; Lewis, N.G. Lignans (neolignans) and allyl/propenyl phenols: Biogenesis, structural biology, and biological/human health considerations. In Comprehensive Natural Products II Chemistry and Biology; Mander, L., Lui, H.-W., Eds.; Elsevier: Oxford, UK, 2010; Volume 1, pp. 815-928.

5. Hamberger, B.; Hahlbrock, K. The 4-coumarate:CoA ligase gene family in Arabidopsis thaliana comprises one rare, sinapate-activating and three commonly occurring isoenzymes. Proc. Natl. Acad. Sci. USA 2004, 101, 2209-2214. [CrossRef] [PubMed]

6. Gui, J.; Shen, J.; Li, L. Functional characterization of evolutionarily divergent 4-coumarate:coenzyme A ligases in rice. Plant Physiol. 2011, 157, 574-586. [CrossRef] [PubMed]

7. Silber, M.V.; Meimberg, H.; Ebel, J. Identification of a 4-coumarate:CoA ligase gene family in the moss, physcomitrella patens. Phytochemistry 2008, 69, 2449-2456. [CrossRef] [PubMed]

8. Becker-Andre, M.; Schulze-Lefert, P.; Hahlbrock, K. Structural comparison, modes of expression, and putative cis-acting elements of the two 4-coumarate:CoA ligase genes in potato. J. Biol. Chem. 1991, 266, 8551-8559. [PubMed]

9. Lozoya, E.; Hoffmann, H.; Douglas, C.; Schulz, W.; Scheel, D.; Hahlbrock, K. Primary structures and catalytic properties of isoenzymes encoded by the two 4-coumarate:CoA ligase genes in parsley. Eur. J. Biochem. 1988, 176, 661-667. [CrossRef] [PubMed]

10. Hu, W.J.; Kawaoka, A.; Tsai, C.J.; Lung, J.; Osakabe, K.; Ebinuma, H.; Chiang, V.L. Compartmentalized expression of two structurally and functionally distinct 4-coumarate:CoA ligase genes in aspen (Populus tremuloides). Proc. Natl. Acad. Sci. USA 1998, 95, 5407-5412. [CrossRef] [PubMed]

11. Banks, J.A. Selaginella and 400 million years of separation. Annu. Rev. Plant Biol. 2009, 60, 223-238. [CrossRef] [PubMed]

12. Weng, J.K.; Noel, J.P. Chemodiversity in Selaginella: A reference system for parallel and convergent metabolic evolution in terrestrial plants. Front. Plant Sci. 2013, 4, 119. [CrossRef] [PubMed] 
13. Wang, W.; Tanurdzic, M.; Luo, M.; Sisneros, N.; Kim, H.R.; Weng, J.K.; Kudrna, D.; Mueller, C.; Arumuganathan, K.; Carlson, J.; et al. Construction of a bacterial artificial chromosome library from the spikemoss Selaginella moellendorffii: A new resource for plant comparative genomics. BMC Plant Biol. 2005, 5, 10. [CrossRef] [PubMed]

14. Banks, J.A.; Nishiyama, T.; Hasebe, M.; Bowman, J.L.; Gribskov, M.; dePamphilis, C.; Albert, V.A.; Aono, N.; Aoyama, T.; Ambrose, B.A.; et al. The Selaginella genome identifies genetic changes associated with the evolution of vascular plants. Science 2011, 332, 960-963. [CrossRef] [PubMed]

15. Stuible, H.P.; Buttner, D.; Ehlting, J.; Hahlbrock, K.; Kombrink, E. Mutational analysis of 4-coumarate:CoA ligase identifies functionally important amino acids and verifies its close relationship to other adenylate-forming enzymes. FEBS Lett. 2000, 467, 117-122. [CrossRef]

16. Kajita, S.; Hishiyama, S.; Tomimura, Y.; Katayama, Y.; Omori, S. Structural characterization of modified lignin in transgenic tobacco plants in which the activity of 4-coumarate:coenzyme A ligase is depressed. Plant Physiol. 1997, 114, 871-879. [CrossRef] [PubMed]

17. Wagner, A.; Donaldson, L.; Kim, H.; Phillips, L.; Flint, H.; Steward, D.; Torr, K.; Koch, G.; Schmitt, U.; Ralph, J. Suppression of 4-coumarate-CoA ligase in the coniferous gymnosperm Pinus radiata. Plant Physiol. 2009, 149, 370-383. [CrossRef] [PubMed]

18. Ehlting, J.; Buttner, D.; Wang, Q.; Douglas, C.J.; Somssich, I.E.; Kombrink, E. Three 4-coumarate:coenzyme A ligases in Arabidopsis thaliana represent two evolutionarily divergent classes in angiosperms. Plant J. 1999, 19, 9-20. [CrossRef] [PubMed]

19. Lee, D.; Meyer, K.; Chapple, C.; Douglas, C.J. Antisense suppression of 4-coumarate:coenzyme A ligase activity in Arabidopsis leads to altered lignin subunit composition. Plant Cell 1997, 9, 1985-1998. [CrossRef] [PubMed]

20. Koutaniemi, S.; Warinowski, T.; Karkonen, A.; Alatalo, E.; Fossdal, C.G.; Saranpaa, P.; Laakso, T.; Fagerstedt, K.V.; Simola, L.K.; Paulin, L.; et al. Expression profiling of the lignin biosynthetic pathway in norway spruce using EST sequencing and real-time RT-PCR. Plant Mol. Biol. 2007, 65, 311-328. [CrossRef] [PubMed]

21. Kumar, A.; Ellis, B.E. 4-coumarate:CoA ligase gene family in Rubus idaeus: cDNA structures, evolution, and expression. Plant Mol. Biol. 2003, 51, 327-340. [CrossRef] [PubMed]

22. Wang, C.H.; Yu, J.; Cai, Y.X.; Zhu, P.P.; Liu, C.Y.; Zhao, A.C.; Lu, R.H.; Li, M.J.; Xu, F.X.; Yu, M.D. Characterization and functional analysis of 4-coumarate:CoA ligase genes in Mulberry. PLoS ONE 2016, 11, e0155814. [CrossRef] [PubMed]

23. Rastogi, S.; Kumar, R.; Chanotiya, C.S.; Shanker, K.; Gupta, M.M.; Nagegowda, D.A.; Shasany, A.K. 4-Coumarate:CoA ligase partitions metabolites for eugenol biosynthesis. Plant Cell Physiol. 2013, 54, 1238-1252. [CrossRef] [PubMed]

24. Liu, T.T.; Yao, R.L.; Zhao, Y.C.; Xu, S.; Huang, C.L.; Luo, J.; Kong, L.Y. Cloning, functional characterization and site-directed mutagenesis of 4-coumarate:coenzyme A ligase (4CL) involved in coumarin biosynthesis in Peucedanum praeruptorum dunn. Front. Plant Sci. 2017, 8. [CrossRef]

25. Chen, H.Y.; Babst, B.A.; Nyamdari, B.; Hu, H.; Sykes, R.; Davis, M.F.; Harding, S.A.; Tsai, C.J. Ectopic expression of a loblolly pine class II 4-coumarate:CoA ligase alters soluble phenylpropanoid metabolism but not lignin biosynthesis in populus. Plant Cell Physiol. 2014, 55, 1669-1678. [CrossRef] [PubMed]

26. Li, Z.B.; Li, C.F.; Li, J.; Zhang, Y.S. Molecular cloning and functional characterization of two divergent 4-coumarate:coenzyme A ligases from Kudzu (pueraria lobata). Biol. Pharm. Bull. 2014, 37, 113-122. [CrossRef] [PubMed]

27. Logan, K.J.; Thomas, B.A. Distribution of lignin derivatives in plants. New Phytol. 1985, 99, 571-585. [CrossRef]

28. Jin, Z.F.; Matsumoto, Y.; Tange, T.; Akiyama, T.; Higuchi, M.; Ishii, T.; Iiyama, K. Proof of the presence of guaiacyl-syringyl lignin in Selaginella tamariscina. J. Wood Sci. 2005, 51, 424-426. [CrossRef]

29. Weng, J.K.; Li, X.; Stout, J.; Chapple, C. Independent origins of syringyl lignin in vascular plants. Proc. Natl. Acad. Sci. USA 2008, 105, 7887-7892. [CrossRef] [PubMed]

30. Yoon, J.; Choi, H.; An, G. Roles of lignin biosynthesis and regulatory genes in plant development. J. Integr. Plant Biol. 2015, 57, 902-912. [CrossRef] [PubMed]

31. Rogers, L.A.; Campbell, M.M. The genetic control of lignin deposition during plant growth and development. New Phytol. 2004, 164, 17-30. [CrossRef] 
32. Weng, J.K.; Akiyama, T.; Bonawitz, N.D.; Li, X.; Ralph, J.; Chapple, C. Convergent evolution of syringyl lignin biosynthesis via distinct pathways in the lycophyte Selaginella and flowering plants. Plant Cell 2010, 22, 1033-1045. [CrossRef] [PubMed]

33. Weng, J.K.; Akiyama, T.; Ralph, J.; Chapple, C. Independent recruitment of an o-methyltransferase for syringyl lignin biosynthesis in Selaginella moellendorffii. Plant Cell 2011, 23, 2708-2724. [CrossRef] [PubMed]

34. Porebski, S.; Bailey, L.G.; Baum, B.R. Modification of a CTAB DNA extraction protocol for plants containing high polysaccharide and polyphenol components. Plant Mol. Biol. Rep. 1997, 15, 8-15. [CrossRef]

35. Gambino, G.; Perrone, I.; Gribaudo, I. A rapid and effective method for RNA extraction from different tissues of grapevine and other woody plants. Phytochem. Anal. PCA 2008, 19, 520-525. [CrossRef] [PubMed]

36. Beuerle, T.; Pichersky, E. Enzymatic synthesis and purification of aromatic coenzyme A esters. Anal. Biochem. 2002, 302, 305-312. [CrossRef] [PubMed]

37. Meng, H.B.; Campbell, W.H. Facile enzymic synthesis of caffeoyl CoA. Phytochemistry 1997, 44, $605-608$. [CrossRef]

38. Obel, N.; Scheller, H.V. Enzymatic synthesis and purification of caffeoyl-CoA, p-coumaroyl-CoA, and feruloyl-CoA. Anal. Biochem. 2000, 286, 38-44. [CrossRef] [PubMed]

39. Phytozome v12.1: Home. Available online: https:// phytozome.jgi.doe.gov/pz/portal.html (accessed on 12 February 2018).

40. Tamura, K.; Dudley, J.; Nei, M.; Kumar, S. Mega4: Molecular evolutionary genetics analysis (MEGA) software version 4.0. Mol. Biol. Evol. 2007, 24, 1596-1599. [CrossRef] [PubMed]

41. Luderitz, T.; Schatz, G.; Grisebach, H. Enzymic synthesis of lignin precursors. Purification and properties of 4-coumarate:CoA ligase from cambial sap of spruce (Picea abies L.). Eur. J. Biochem. 1982, 123, 583-586. [CrossRef] [PubMed]

42. Stockigt, J.; Zenk, M.H. Chemical syntheses and properties of hydroxycinnamoyl-coenzyme a derivatives. Z. Naturforsch. C 1975, 30, 352-358. [PubMed]

Sample Availability: Samples of the compounds $p$-Coumaroyl CoA, dihydro- $p$-coumaroyl CoA, caffeoyl CoA, and feruloyl CoA are available from the authors.

(C) 2018 by the authors. Licensee MDPI, Basel, Switzerland. This article is an open access article distributed under the terms and conditions of the Creative Commons Attribution (CC BY) license (http:/ / creativecommons.org/licenses/by/4.0/). 